Philosophy and Progress: Vols. LXI-LXII, January-June, July-December, 2017 ISSN 1607-2278 (Print), DOI : https://doi.org/10.3329/pp.v61i1-2.44205

\section{A BEHAVIOURAL STUDY ON THE INFLUENCES OF CONFUCIANISM IN CHINESE SOCIETY}

\author{
Helal Uddin Ahmed* \\ Zhang Jielin ${ }^{* *}$
}

\begin{abstract}
Confucius (551-479 BC) is considered to be a great philosopher and educator in Chinese society and one of the greatest scholars ever in world history. He was the founder of Confucianism, which constitutes a major part of traditional Chinese culture and made tremendous contribution to the unfolding of Chinese civilization over the centuries. In this study, the authors have presented a comprehensive outline of Confucianism and have attempted to gauge the attitude of contemporary Chinese people towards Confucian concepts, values and attributes as well as their influences on the social lives of present-day Chinese population. The Likert Scale was applied in the study to assess the attitude of the Chinese educated class belonging to the educational institutions like the universities in

Retired Additional Secretary, Bangladesh Government, Former Editor, Bangladesh Quarterly, Dhaka, Bangladesh,

E-mail: hahmed1960@gmail.com

** Project Officer, Division of Confucius Institute Development, Beijing Language and Culture University, People's Republic of China. E-mail : paopaoazure@163.com
\end{abstract}

Beijing towards Confucianism. It was found from the survey that the Confucian concepts still wield substantial influence on the social outlook of the modern-day Chinese people and these attributes are still relevant in the day to day lives of the Chinese society.

\section{Introduction to Confucius and Confucianism}

The ancient Chinese Philosopher Kong Fuzi or Confucius (551$479 \mathrm{BC}$ ) is unparalleled in the history of human civilization as a focus of cultural significance, a founder of cultural institution and a model of ethical behaviour. He was surnamed Kong and his given name was Qiu; he styled himself as Zhongni. ${ }^{1} \mathrm{He}$ is considered to be one of the greatest thinkers and educators in Chinese history and one of the greatest scholars of all time in world history. His ideology and teachings constitute a major part of traditional Chinese culture. ${ }^{2}$ Even today, Confucianism is widely considered to be a foundation of society, custom and culture in contemporary China. ${ }^{3}$ Born in Zouyi in the state of $\mathrm{Lu}$ (in the south-east of today's Qufu) in a region comprising the south-eastern part of present-day Shandong province, he was alive during the decline of the Zhou dynasty (1100-256 $\mathrm{BC})$ in the late 'Spring and Autumn Period'. His vision about the path to social and political harmony was founded upon the rites and institutions set in motion by the Duke of Zhou five hundred years earlier. ${ }^{4}$ These institutions largely contributed to the emergence of the Chinese civilization. The Zhou feudal system prescribed the family relations as the basis of political loyalties. The family constituted the context within which the individual became what he or she was, and the state itself was patterned upon the model of the family.

It could be gathered that Confucius spent the last years of his life in editing and completing his books, which became known as the Five Classics. These were: 'Classic of Poetry', 'Classic of History', 'Spring and Autumn Annals', 'Record of 
Rites' and the 'Classic of Changes'. Four other works included 'Lun-yu' or 'Analects' - a representative compilation of Confucian philosophy - which recorded his life and teachings by his own disciples. It is considered by scholars to be the most reliable source regarding the doctrine of Confucius and it covers almost all his basic philosophical concepts. ${ }^{5}$ The initial parts of this representative work contain his personal remembrances as a human being, and the later parts, particularly the last five of the twenty chapters, were probably produced when Confucius' main disciples started their careers as transmitters of the Confucian way, where they often spoke in their own voices. The Analects of Confucius has always been considered by the Chinese people as a classic over the past two and a half thousand years. It embodies the political ideas, ethics, and principles of education and its core value was benevolence.

Confucius emphasized the ideology of benevolence (ren) on the part of rulers toward their subjects and stressed that the political rule should be backed by virtue - not by force. He was staunchly against exploitation of the oppressed people and advocated people's rule based on morality - not tyranny. Confucius was also a great educator and taught his disciples without discrimination, irrespective of their socio-economic background or status. It is said that Confucius taught as many as 3,000 disciples, of whom 72 became very famous. He proposed teaching students according to their aptitude and opined that one should be honest in learning and not pretend to know what he did not know. He also asked his pupils to regularly review what they learned from their studies, as new knowledge could be gained by reviewing the old knowledge. ${ }^{6}$

Impact of Confucianism on Chinese Society It is often claimed that the Confucian theories helped crystallize the ruling ideology in the vast nation of China for over two and a half thousand years. Confucius stressed five relationships as key to a stable and harmonious society: that between the ruler and subject, between father and son, between husband and wife, between elder and younger brother, and among friends. The first four relationships were unequal, as the first person was considered superior to the second. The fifth relationship or friendship was, however, equal and based on love and mutual respect. Overall, dutifulness combined with sincerity and dedication was considered to be the pathway to social harmony. The major Confucian concepts included benevolence or humaneness, rectification of names, doctrine of the mean, the concept of superior man or exemplary person, filial piety, heaven, will, fate, proper conduct or ritual, the way or path of virtue, and using oneself to gauge others.

The members of the administrative or civil service system of the traditional Chinese government since the ancient era were selected through a competitive examination, which gave the Chinese empire stability for over 2,000 years and also provided for mobility in the society. ${ }^{7}$ Later on, it served as a model for civil service systems in many Asian and Western countries. The civil service examination system, which had its beginnings during the Sui dynasty (581-618 AD) and was fully developed during the Qing dynasty (1616-1911), was squarely founded upon the Confucian classics and their recognised commentaries.

The Qin dynasty (221-207 BC) first established the Chinese bureaucratic empire by installing an administrative system. It was then adopted by the Han dynasty (206 BC-220 $\mathrm{AD})$, who in $124 \mathrm{BC}$ established an imperial university to train and test officials in the techniques of Confucian governance. ${ }^{8}$ This system was adopted by the Sui dynasty (581-618 AD), who applied it to recruit officials in a systematic way. They also introduced appointment of central government officials at 
the local level. After that, the Tang dynasty (608-907) introduced the 'Jinshi' examination, which tested an aspiring civil servants' knowledge about Confucian classics for induction into higher levels of civil service. This system was gradually incorporated as the main method of recruiting civil servants, and these non-hereditary elites ultimately became known to the Western countries as 'Mandarins' based on the Chinese dialect they used. This administrative system reached its zenith during the Song dynasty (960-1279), when public schools were set up for the masses throughout the empire and promotions were based on merit and the conduct of civil servants. The 'Jinshi' degree on Confucianism was an essential prerequisite for reaching higher levels of bureaucracy. The Chinese civil service reached its final form during the Ming dynasty (1368-1644), which was also copied by the succeeding Qing dynasty (1644-1911/12). The latter, however, abolished the examination system in 1905, and the prevailing civil service system was ultimately abolished after the overthrow of the Qing dynasty in 1911-12.9

Confucianism is not a religion in the strictest sense. Rather, it is a practical philosophy and a guide to morality and good governance that has affected everything across China, from education, government, public outlook, private attitude, to etiquette, morality and ethics. It is a complex system of social and political values based on filial piety, kinship, loyalty and righteousness. The teachings of Confucius covered a wide range of themes - from how a true gentleman should behave in his day-to-day life to how a ruler should govern. It is a moral guide for good governance - one that values hierarchy, group orientation, respect for elders and the tradition. Confucius was interested about instilling order and harmony in a turbulent society. He opined that mankind would be in harmony with the universe if people understood their ranks in society and were taught appropriate behaviour commensurate with their ranks. In the same vein, he believed that societal order was compromised whenever individuals failed to act according to their prescribed roles. He focused on a system of interdependent relationships where the lower levels displayed obedience to the higher levels, which extended from the family to the nation. In contrast to the Western bias for individualism, collectivism is inherent in a Confucian society, where it is necessary to attune one's desires to the greater good of the group, and where an individual is defined by his or her relationship to the group.

It is often argued that the Chinese people have been culturally conditioned by the Confucian view of looking at things in terms of collective responsibility, specifically for their families, the community and the nation at large. Confucius laid much emphasis on education and scholarship, which greatly influenced other countries of the East and Southeast Asia region including Korea, Japan, Vietnam, Laos, Cambodia and Singapore. His philosophy directly gave rise to the imperial examination system for the civil service in the $7^{\text {th }}$ Century AD, whereby attempts were made to replace hereditary rule by aristocracy with a system based on meritocracy. Confucianism was declared as the official state philosophy by the Han dynasty (BC 206 - AD 220) in the $2^{\text {nd }}$ Century BC, and it has remained as a dominant orthodoxy in Chinese society over the last two and a half thousand years. In 2006, the then Chinese President $\mathrm{Hu}$ Jintao called on the Chinese civil servants to adopt Confucian morality and ethics as a means to counter corruption and inequality in society. He also sanctioned funding for establishing over 100 'Confucian Institutes' across the globe to reinforce and strengthen education and research on the Chinese language and culture around the globe. 


\section{Behavioural Approach in Social Science}

Originating in the USA in the middle of the Twentieth Century, behavioural approach has been one of the most important developments during that century in the study of Political Science. It implied a search for realism based on a scientific outlook. The attainment of depth and realism in the study of political systems enabled a researcher to locate the dynamic forces of society wherever they existed - in social classes, cultures, socio-economic transformations, political elites and international affairs. This empirical method or approach is therefore based on reality, which entailed studying the actual behaviour of individuals and groups playing socio-political roles instead of merely examining laws, rules and ideological patterns.

According to Heinz Eulau, modern behavioural science is concerned not only with the acts of man, but also with his cognitive, effective and evaluative processes. ${ }^{10}$ Behavioural approach in social science, therefore, refers not only to directly or indirectly observable social actions, but also to those perceptual, motivational and attitudinal components of behaviour which contributes to man's social identification, demands and systems of benefits, values and goals. ${ }^{11}$

\section{Objectives of the Study}

The overall objective of this study was to undertake an assessment of the impact of Confucianism on the society in China over the years, especially by focusing on the present times. The specific objectives of this study were:

(a) To undertake a behavioural study on the influences of Confucian values and ethics on the society in China by focusing on the learned academic community in society, viz. teachers and students based in the Chinese capital Beijing.

(b) To gauge whether Confucianism is considered to be a practical philosophy of life or a religion by the learned academic community in society.

(c) To identify the challenges for attuning the Chinese society in line with the Confucian philosophy.

\section{Methodology of the Study}

An empirical research approach with a qualitative orientation was followed in this study. ${ }^{12}$ The nature of enquiry was descriptive and responses were analysed both qualitatively and quantitatively. ${ }^{13}$ The primary research strategy was survey through purposive sampling on the basis of limited-choice structured questionnaires by applying the 'Likert Scale' for gauging the attitude of respondents. ${ }^{14}$ Developed by Rensis Likert, 'Likert Scale' is the most widely used variation of the summated rating scale (usually scale of 5 points, ranging from strong disagreement to strong agreement). It consists of statements that express either a favourable or unfavourable attitude towards the object of interest, and the respondents are asked to agree or disagree with each statement.

The distribution of points for the Likert Scale was as follows in this study: Strongly Agree $=+2$; Agree $=+1$; Undecided or Neutral $=0$; Disagree $=-1$; Strongly Disagree $=-$ 2. Besides, focus group discussions (FGD) were also organized to elicit views and opinions on the subject from relevant stakeholders. Observation techniques were applied when required (as during field visits and interviews) and data from secondary sources were used where appropriate (such as in literature review). Behavioural, socio-economic and 
governance indicators were applied for evaluating relevant variables.

\section{Scope and Limitations of the Study}

The present study aimed to incorporate and correlate the views, perceptions and experiences of relevant teachers and pupils belonging to the academic community in China on the impact of Confucianism in Chinese society. This is likely to provide newer insights into the impact of Confucian values and ethics on the society in China and how it could be carried forward for promoting social amity and cohesion in this great nation.

The research, however, had limitations due to the fact that it covered only the teachers and students at the universities in the Chinese capital Beijing. The study was also constrained to some extent due to the application of non-probability purposive sampling, as probability sampling was not feasible because of time and resource constraints. However, the samples were representative ones for the relevant population and standard practices followed in this kind of research were complied with fully.

\section{Findings from the Survey}

The findings from the questionnaire survey conducted among 15 teachers and 15 students of Chinese society on the basis of 20 questions related to the influences of Confucianism have been summarised below on a question by question basis. As mentioned earlier, the Likert scale scores ranged from +2 to -2 , and were interpreted as follows: strongly agree (2.0), agree (1.0), neutral or undecided (0), disagree (-1.0) and strongly disagree (-2.0). This implied that a score above 0 (positive score) meant positive attitude, while a score below 0 (negative score) meant negative attitude.
1. Relevance of Confucian Values and Ethics for Personal \& Family Life: This question was of a general nature and the average Likert scale score as shown in Table-1 demonstrates that a majority of the Chinese people still believe that the Confucian values and ethics have relevance for their personal and family lives.

\section{Table-1: Are Confucian values and ethics relevant to personal and family life}

\begin{tabular}{|l|l|}
\hline Respondent Category & Likert Scale Score (Average) \\
\hline Teachers & 0.80 \\
\hline Students & 1.20 \\
\hline OVERALL & 1.00 \\
\hline
\end{tabular}

2. Superiority of the Ruler to the Subject: This question verified whether the Confucian view of superiority of the ruler over the subject still holds true in the minds of the Chinese people. The result, as shown in Table-2, again demonstrates a positive attitude with regard to the subject among the respondents.

\section{Table-2: Is the ruler superior to the subject}

\begin{tabular}{|l|l|}
\hline Respondent Category & Likert Scale Score (Average) \\
\hline Teachers & 0.60 \\
\hline Students & 0.87 \\
\hline OVERALL & 0.73 \\
\hline
\end{tabular}

3. Superiority of Father to Son: This question also ascertains the traditional Confucian view of superiority of father to the son. The survey findings again reflect this view among the Chinese people by showing a positive correlation based on the Likert scale score. However, the students appear to be much more supportive of the view compared to the careerist teachers. 
Table-3: Is the father superior to the son

\begin{tabular}{|l|l|}
\hline Respondent Category & Likert Scale Score (Average) \\
\hline Teachers & 0.40 \\
\hline Students & 0.87 \\
\hline OVERALL & 0.63 \\
\hline
\end{tabular}

4. Superiority of Husband to Wife: A majority of the respondents did not agree with the traditional Confucian view that husbands were superior to their wives, as demonstrated by a negative Likert scale score. This negativity is more pronounced among the teachers, many of whom are married. This also reflects the impact of modernity as well as a Marxist egalitarian attitude among the Chinese population.

Table-4: Is the husband superior to the wife

\begin{tabular}{|l|l|}
\hline Respondent Category & Likert Scale Score (Average) \\
\hline Teachers & -1.33 \\
\hline Students & -0.60 \\
\hline OVERALL & -0.96 \\
\hline
\end{tabular}

5. Superiority of Elder Brother to Younger Brother: This traditional Confucian view has again been negated by a majority of the respondents, as evidenced from the negative Likert scale score. This may also be a reflection of the communist egalitarian outlook of the Chinese people, who consider all to be equals.

Table-5: Is the elder brother superior to the younger brother

\begin{tabular}{|l|l|}
\hline Respondent Category & Likert Scale Score (Average) \\
\hline Teachers & -0.27 \\
\hline Students & -0.20 \\
\hline OVERALL & -0.23 \\
\hline
\end{tabular}

6. Equal Treatment and Mutual Love and Respect for Friends: The Confucian ideology of equal treatment and mutual love cum respect for friends received the strongest backing from respondents as evidenced from the average Likert scale score of 1.73 (maximum possible 2). Therefore, this trait or characteristic is highly correlated with the general outlook of the Chinese people. This has been found to be particularly strong among the teachers (average Likert scale score of 1.87), who are generally considered to be mature professionals who prize ethical values.

\section{Table-6: Whether friends deserve equal treatment and mutual love cum respect}

\begin{tabular}{|l|l|}
\hline Respondent Category & Likert Scale Score (Average) \\
\hline Teachers & 1.87 \\
\hline Students & 1.60 \\
\hline OVERALL & 1.73 \\
\hline
\end{tabular}

7. Belief in and Practice of Benevolence/Humaneness: The Confucian trait of benevolence also received good support from the sample population, with an average Likert scale score of 0.96 . The difference between the teachers and students has also been found to be marginal, which may be attributed to a more materialistic attitude among the teachers.

\section{Table-7: Belief in benevolence/humaneness (Ren) and} practicing it in life

\begin{tabular}{|l|l|}
\hline Respondent Category & Likert Scale Score (Average) \\
\hline Teachers & 0.93 \\
\hline Students & 1.00 \\
\hline OVERALL & 0.96 \\
\hline
\end{tabular}


8. Belief in and Practice of the 'Doctrine of Mean': The Confucian attribute of belief in and practice of the 'doctrine of mean' received good support from the sampled teachers (average Likert scale score of 1), but not so strong support (average Likert scale score of 0.60) from the sampled students. This may have been due to a lack of understanding or appreciation of the concept among the students.

Table-8: Belief in 'doctrine of the mean' (Zhongyong) and practicing it in life

\begin{tabular}{|l|l|}
\hline Respondent Category & Likert Scale Score (Average) \\
\hline Teachers & 1.00 \\
\hline Students & 0.60 \\
\hline OVERALL & 0.80 \\
\hline
\end{tabular}

9. Belief in and Practice of Superior/Exemplary Person Concept: The Confucian ideal of belief in and practice of superior/exemplary person concept also received moderate support from the teachers and students. It demonstrates that the Chinese people are appreciative of the behaviour and performance of superior or exemplary persons, whom they try to emulate in different spheres. This is also in line with the traditional Chinese culture as well as prevailing social custom.

\section{Table-9: Belief in 'superior/exemplary person' (Junzi)} concept and practicing it in life

\begin{tabular}{|l|l|}
\hline Respondent Category & Likert Scale Score (Average) \\
\hline Teachers & 1.07 \\
\hline Students & 0.93 \\
\hline OVERALL & 1.00 \\
\hline
\end{tabular}

10. Belief in and Practice of 'Filial Piety' Concept: The traditional Confucian trait of filial piety also received wide support from both the sampled teachers and sampled students, with an average Likert scale score of 1.23. It demonstrates that the Chinese families still value family bondage as well as dutifulness of family members towards each other.

\section{Table-10: Belief in the 'filial piety' (Xiao) concept and practicing it in life}

\begin{tabular}{|l|l|}
\hline Respondent Category & Likert Scale Score (Average) \\
\hline Teachers & 1.27 \\
\hline Students & 1.20 \\
\hline OVERALL & 1.23 \\
\hline
\end{tabular}

11. Belief in and Practice of the Concept of Heaven: The Confucian concept of heaven received weak support from the respondents (average Likert scale score of 0.43), although the overall Likert scale score was positive. This shows a broad but weak conviction about heaven as propounded by Confucius.

\section{Table-11: Belief in the concept of 'heaven' (Tian) and practicing it in life}

\begin{tabular}{|l|l|}
\hline Respondent Category & Likert Scale Score (Average) \\
\hline Teachers & 0.47 \\
\hline Students & 0.40 \\
\hline OVERALL & 0.43 \\
\hline
\end{tabular}

12. Belief in and Practice of the Concept of Fate: The Confucian concept of fate was also accorded weak support by the respondents, as demonstrated by the average Likert 
scale score of 0.60 , although the overall outlook was again found to be positive.

\section{Table-12: Belief in the concept of 'fate' (Ming) and} practicing it in life

\begin{tabular}{|l|l|}
\hline Respondent Category & Likert Scale Score (Average) \\
\hline Teachers & 0.80 \\
\hline Students & 0.40 \\
\hline AVERAGE & 0.60 \\
\hline
\end{tabular}

13. Belief in and Practice of the Concept of Proper Conduct/Ritual: The traditional Confucian concept of proper conduct or rituals received good support as evidenced by the average Likert scale score of 0.86 . This is also reinforced by the fact that the Chinese people still appear to be, by and large, adherents of rituals and custom.

Table-13: Belief in the concept of 'proper conduct/ritual' (Li) and practicing it

\begin{tabular}{|l|l|}
\hline Respondent Category & Likert Scale Score (Average) \\
\hline Teachers & 0.93 \\
\hline Students & 0.80 \\
\hline OVERALL & 0.86 \\
\hline
\end{tabular}

14. Belief in and Practice of the Concept of 'Path of Virtue': The traditional Confucian concept of 'Dao' or path of virtue also received good support from the respondents. Overall, the attitude among both teachers and students seems to be moderately positive as reflected by the average Likert scale score of 0.80 .
Table-14: Belief in the concept of 'way or path of virtue' (Dao) and practicing it

\begin{tabular}{|l|l|}
\hline Respondent Category & Likert Scale Score (Average) \\
\hline Teachers & 0.73 \\
\hline Students & 0.87 \\
\hline OVERALL & 0.80 \\
\hline
\end{tabular}

15. Belief in and Practice of the Concept of 'Using Oneself to Gauge Others': The customary Confucian concept of 'using oneself to gauge others' did not receive good support from the students ( 0.40 Likert scale score), although the score was better in case of the teachers $(0.87$ score). Overall, the attitude towards the concept appeared to be positive among the Chinese people.

\section{Table-15: Belief in the concept of 'using oneself to gauge others' (Shu) and practicing it}

\begin{tabular}{|l|l|}
\hline Respondent Category & Likert Scale Score (Average) \\
\hline Teachers & 0.87 \\
\hline Students & 0.40 \\
\hline OVERALL & 0.63 \\
\hline
\end{tabular}

16. Relevance of Confucianism to Professional Life: The respondents were also asked about the relevance of Confucianism in their professional lives, which elicited a weak but positive response in terms of average Likert scale score $(0.73)$. The score was especially weak among the students (0.67), who, in fact, have not started their professional careers. 


\section{Table-16: Are Confucian values still relevant for} professional life

\begin{tabular}{|l|l|}
\hline Respondent Category & Likert Scale Score (Average) \\
\hline Teachers & 0.80 \\
\hline Students & 0.67 \\
\hline OVERALL & 0.73 \\
\hline
\end{tabular}

17. Relevance of Confucian Values and Ethics to Social Life: The average Likert scale score for the relevance of Confucian values and ethics to social life was better, with the teaching professionals recording a strong score of 1.07.

Table-17: Are Confucian values and ethics still relevant to social life

\begin{tabular}{|l|l|}
\hline Respondent Category & Likert Scale Score (Average) \\
\hline Teachers & 1.07 \\
\hline Students & 0.80 \\
\hline OVERALL & 0.93 \\
\hline
\end{tabular}

18. Relevance of Confucian Values and Ethics for Economic Life: Although the average Likert scale score for the relevance of Confucian values and ethics to economic life was found to be positive, it was found to be have low correlation among both the teachers and students, the overall average being 0.23 .

Table-18: Are Confucian values and ethics still relevant to economic life

\begin{tabular}{|l|l|}
\hline Respondent Category & Likert Scale Score (Average) \\
\hline Teachers & 0.13 \\
\hline Students & 0.33 \\
\hline OVERALL & 0.23 \\
\hline
\end{tabular}

19. Confucianism as a Practical Philosophy of Life: The relevance of Confucianism as a practical philosophy of life received moderate support from teachers and students, the average Likert scale score being 0.96. The Chinese people, therefore, appear to have no objection to the treatment of Confucianism as a practical philosophy of life.

Table-19: Acceptance of Confucianism as a practical philosophy of life

\begin{tabular}{|l|l|}
\hline Respondent Category & Likert Scale Score (Average) \\
\hline Teachers & 1.00 \\
\hline Students & 0.93 \\
\hline OVERALL & 0.96 \\
\hline
\end{tabular}

20. Confucianism as a Type of Religion: As was expected, Confucianism was not condoned as a kind of religion by both the categories of respondents. The negative average Likert scale score of -0.50 shows that although the Chinese people are ready to accept Confucianism as a practical philosophy of life, they are not generally predisposed to recognizing it as a type of religion, which tallies with the concept of Confucianism.

\section{Table-20: Acceptance of Confucianism as a kind of religion}

\begin{tabular}{|l|l|}
\hline Respondent Category & Likert Scale Score (Average) \\
\hline Teachers & -0.40 \\
\hline Students & -0.60 \\
\hline OVERALL & -0.50 \\
\hline
\end{tabular}

21. Overall Assessment: Overall, the respondents appeared to be supportive of the influences of Confucianism in society in case of 90 percent of the questions (18 questions out of 20, with 17 indicating positive attitude and 1 showing negative attitude), while the two Confucian traits they differed with (negative attitude about superiority of elder brother and husband) violated an egalitarian Marxist principle that they generally uphold. 
Therefore, it can be safely claimed that although not very strong, Confucianism still holds sway, in general, in the minds of the present-day Chinese population and society.

Table-21: Influences of Confucianism on Chinese Society: Overall Survey Findings

\begin{tabular}{|c|c|c|}
\hline $\begin{array}{l}\text { Sl. } \\
\text { No. }\end{array}$ & Questions & $\begin{array}{c}\text { Average } \\
\text { Likert Scale } \\
\text { Score }\end{array}$ \\
\hline 1. & $\begin{array}{l}\text { Are Confucian values and ethics relevant to } \\
\text { your personal and family life? }\end{array}$ & 1.00 \\
\hline 2. & Is the ruler superior to the subject? & 0.73 \\
\hline 3. & Is the father superior to the son? & 0.63 \\
\hline 4. & Is the husband superior to the wife? & -0.96 \\
\hline 5. & $\begin{array}{l}\text { Is the elder brother superior to the younger } \\
\text { brother? }\end{array}$ & -0.23 \\
\hline 6. & $\begin{array}{l}\text { Do friends deserve equal treatment and } \\
\text { mutual love and respect? }\end{array}$ & 1.73 \\
\hline 7. & $\begin{array}{l}\text { Do you believe in benevolence/ humaneness } \\
\text { (Ren) and practice it in your life? }\end{array}$ & 0.96 \\
\hline 8. & $\begin{array}{l}\text { Do you believe in 'doctrine of the mean' } \\
\text { (Zhongyong) and practice it in your life? }\end{array}$ & 0.80 \\
\hline 9. & $\begin{array}{l}\text { Do you believe in 'superior/exemplary } \\
\text { person' (Junzi) concept and practice it in life? }\end{array}$ & 1.00 \\
\hline 10. & $\begin{array}{l}\text { Do you believe in the 'filial piety' (Xiao) } \\
\text { concept and practice it in your life? }\end{array}$ & 1.23 \\
\hline 11. & $\begin{array}{l}\text { Do you believe in the concept of 'heaven' } \\
\text { (Tian) and practice it in your life? }\end{array}$ & 0.43 \\
\hline 12. & $\begin{array}{l}\text { Do you believe in the concept of 'fate' (Ming) } \\
\text { and practice it in your life? }\end{array}$ & 0.60 \\
\hline 13. & $\begin{array}{l}\text { Do you believe in the concept of 'proper } \\
\text { conduct/ritual' }(\mathrm{Li}) \text { and practice it? }\end{array}$ & 0.86 \\
\hline 14. & $\begin{array}{l}\text { Do you believe in the concept of 'way or path } \\
\text { of virtue' (Dao) and practice it? }\end{array}$ & 0.80 \\
\hline 15. & $\begin{array}{l}\text { Do you believe in the concept of 'using } \\
\text { oneself to gauge others' }(S h u) \text { and practice it? }\end{array}$ & 0.63 \\
\hline 16. & $\begin{array}{l}\text { Are Confucian values still relevant to your } \\
\text { professional life? }\end{array}$ & 0.73 \\
\hline
\end{tabular}

\begin{tabular}{|c|l|c|}
\hline 17. & $\begin{array}{l}\text { Are Confucian values and ethics still relevant } \\
\text { to your social life? }\end{array}$ & 0.93 \\
\hline 18. & $\begin{array}{l}\text { Are Confucian values and ethics still relevant } \\
\text { to your economic life? }\end{array}$ & 0.23 \\
\hline 19. & $\begin{array}{l}\text { Do you accept Confucianism as a practical } \\
\text { philosophy of life? }\end{array}$ & 0.96 \\
\hline 20. & $\begin{array}{l}\text { Do you accept Confucianism as a kind of } \\
\text { religion? }\end{array}$ & -0.50 \\
\hline & AVERAGE LIKERT SCALE SCORE & $\mathbf{0 . 6 3}$ \\
\hline
\end{tabular}

Table 22: Demographic Profiles of Respondents (Total: 30 )

\begin{tabular}{|c|c|c|c|c|c|c|c|c|c|}
\hline \multicolumn{2}{|c|}{ Profession } & \multicolumn{2}{|c|}{ Age (years) } & \multicolumn{2}{|c|}{ Gender } & \multicolumn{2}{|c|}{ Education } & \multicolumn{2}{|c|}{$\begin{array}{c}\text { Marital } \\
\text { Status }\end{array}$} \\
\hline 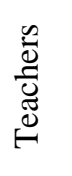 & 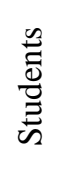 & $20-30$ & $30-45$ & $\frac{0}{\sqrt[\pi]{2}}$ & $\begin{array}{l}\frac{0}{\widetilde{\Xi}} \\
\text { ฮี } \\
\text { I. }\end{array}$ & 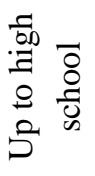 & 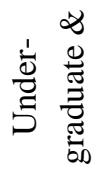 & 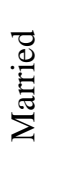 & 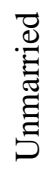 \\
\hline 15 & 15 & 23 & 7 & 11 & 19 & $\mathbf{0}$ & 30 & 10 & 20 \\
\hline
\end{tabular}

\section{Conclusion}

It is clear from the above analysis that Confucian values and views or Confucianism still have moderate influences in the Chinese society of the modern era, around two and a half thousand years after it was originally propounded. This ideological mooring has, in fact, provided the Chinese nation with a social stability and predictability that has been nurtured and sustained throughout the ages. Thus, it can be safely claimed that the Chinese society is still, by and large, a Confucian one, and is most likely to continue as such during the coming decades as well, despite a rising tide of economic and cultural globalisation all over the world and its increasing impact on Chinese society in the recent past. 


\section{References}

1. The Overseas Chinese Affairs Office of the State Council, Common Knowledge about Chinese History, (Beijing: Higher Education Press, 2015), p. 29.

2. BLCU, The Analects of Confucius with Illustrations: A Complete Translated Version, (Beijing: Beijing Language and Culture University Press, 2016), Foreword.

3. David L. Hall, "Confucius", in A companion to the Philosophers ed. by R. L. Arrington (London: Blackwell Publishers, 1999), 52-57.

4. David L. Hall, "Confucius", in A companion to the Philosophers ed. by R. L. Arrington (London: Blackwell Publishers, 1999), 52-57.

5. Confucius, The Analects, translated by D. C. Lau, (Hong Kong: Chinese University Press, 1992).

6. The Overseas Chinese Affairs Office of the State Council, Common Knowledge about Chinese History, (Beijing: Higher Education Press, 2015), p. 29.

7. Encyclopedia Britannica, "Chinese Civil Service", Encyclopedia Britannica Ultimate Reference Suite, (Chicago: Encyclopedia Britannica, 2012).

8. Encyclopedia Britannica, "Chinese Civil Service", Encyclopedia Britannica Ultimate Reference Suite, (Chicago: Encyclopedia Britannica, 2012).

9. 1 Encyclopedia Britannica, "Chinese Civil Service", Encyclopedia Britannica Ultimate Reference Suite, (Chicago: Encyclopedia Britannica, 2012).

10. Heinz Eulau, The Behavioural Persuasion in Politics, (New York: Random House, 1963).

11. R. C. Agarwal, Political Theory, $8^{\text {th }}$ Edition, (New Delhi: S. Chand and Company Ltd., 2003), 33.
12. C. R. Kothari, Research Methodology: Methods and Techniques, $2^{\text {nd }}$ Edition, (New Delhi: Vishwa Prakashan, 1990), 3-6.

13. W. M. K. Trochim, Research Methods, $2^{\text {nd }}$ Edition, (USA: Atomic Dog Publishing, 2003).

14. M. Denscombe, The Good Research Guide, $2^{\text {nd }}$ Edition, (Maidenhead: Open University Press, 2003), pp. 6-27, 144-159, 163-189, 233-263.

\section{Bibliography}

Agarwal, R .C., Political Theory, $8^{\text {th }}$ Edition. New Delhi: S. Chand and Company Ltd., 2003.

Beijing Language and Culture University (BLCU). The Analects of Confucius with Illustrations: A Complete Translated Version. Beijing: Beijing Language and Culture University Press, 2016.

Burns, John P., "Civil Service Reform in China", OECD Journal on Budgeting, Volume 7, No. 1, 2007.

Confucius, The Analects, translated by D. C. Lau. Hong Kong: Chinese University Press, 1992.

Denscombe, M., The Good Research Guide, $2^{\text {nd }}$ Edition. Maidenhead: Open University Press, 2003.

Encyclopedia Britannica, "Chinese Civil Service", Encyclopedia Britannica Ultimate Reference Suite. Chicago: Encyclopedia Britannica, 2012.

Eulau, Heinz. The Behavioural Persuasion in Politics. New York: Random House, 1963.

Hall, David L., "Confucius", in A companion to the Philosophers, ed. by R. L., Arrington. London: Blackwell Publishers, 1999.

Kothari, C. R. Research Methodology: Methods and Techniques, $2^{\text {nd }}$ Edition. New Delhi: Vishwa Prakashan, 1990.

Law, Eugene, Inter-continental's Best of China. Beijing: China Intercontinental Press, 2004. 
The Overseas Chinese Affairs Office of the State Council \& The Office of Chinese Language Council International. Common Knowledge about Chinese History. Beijing: Higher Education Press, 2015.

Trochim, W. M. K., Research Methods, $2^{\text {nd }}$ Edition. USA: Atomic Dog Publishing, 2003.

Wikipedia, "Civil Service of the People's Republic of China", (https://en.wikipedia.org/wiki/Civil_Service of the People's_R epublic_of_China, accessed on 18 February 2017). 